\title{
Body Composition in Diabetes Mellitus
}

\author{
Dr. I. Soniya ${ }^{1}$, Dr. M. Anita Devi ${ }^{2}$, Dr. Sp. Rosemary ${ }^{3}$ \\ 1. Post Graduate trainee, Department of Physiology, Regional Institute of Medical Sciences, Imphal -795004 \\ 2. Prof. \& Head, Department of Physiology, Regional Institute of Medical Sciences, Imphal -795004. \\ 3. Post Graduate trainee, Department of Physiology, Regional Institute of Medical Sciences, Imphal -795004
}

\begin{abstract}
Objective: To determine the body composition and its relationship with type 2diabetes. Materials and Methods: A cross sectional study of 100 Type 2 diabetic patients in age group between 30 to 78 years attending diabetic clinic, RIMS, Imphal was conducted during October 2011 to September 2012. BMI and body composition were determined by using Omron body composition Analyser.

Results: The mean $\pm S D$ of BMI were $24.5 \pm 2$ and $25.96 \pm 3$ in males and females respectively. Body Fat\% was $28.5 \pm 6$ and $35 \pm 5$ in males and females respectively. BMI and fat \% is positively correlated in these patients.

Conclusion: In this study, fat \% was found to be significantly correlated with BMI and the body fat \% of female is higher as compared to male.
\end{abstract}

Key words: Type 2 diabetes, body mass index, body composition, fat $\%$.

\section{Introduction}

Diabetes mellitus refers to a group of common metabolic disorder that share the phenotype of hyperglycemia. ${ }^{1}$ There is an alarming increase in the incidence and prevalence of Diabetes mellitus. ${ }^{2}$ The prevalence of Type 2 diabetes could also be different in various races due to environmental difference. ${ }^{3}$

Type 2 diabetes mellitus is characterized by impaired insulin secretion, insulin resistance, excessive hepatic glucose production and abnormal fat metabolism. Insulin resistance, the decreased ability of insulin to act effectively on target tissues (especially muscle, liver, and fat) results from a combination of genetic susceptibility and obesity. ${ }^{4}$ Obesity particularly visceral, central (evidenced by the hip waist ratio) is very common in type 2 diabetes. ${ }^{5}$ The increased adipocyte mass leads to increased level of free fatty acid and other fat cell product which further increases insulin resistance in the skeletal muscle and liver. In contrast, the production by adipocytes of adiponectin, an insulin sensitizing peptide is reduced in obesity and this may contribute to hepatic insulin resistance. ${ }^{6}$ Regional adipose tissue deposition are known to vary in terms of physiology which helps to explain relationship between diabetes and fat location. Fat mass comprises of essential fat and storage fat. Essential fat is required for normal physiological function whereas storage fat is primarily adipose tissue.?

Body composition and fat deposition may be altered by the disease process ${ }^{8}$. Body fat can be estimated in the clinic or in the surveys using waist circumference or subcutaneous skin fold thickness with surprising accuracy. In practice, BMI $\left(\mathrm{kg} / \mathrm{m}^{2}\right)$ is more often used although it is less specific for body fat. The body fat ranges for optimal health (20\%-30\% for women and 10\%-20\% for men based on the reference from Obesity assessment recommended by Lohman (1986) and Nagamine (1972). Two major goals of the diabetes therapy are to reduce hyperglycemia and body weight to avoid chronic complications especially to the eyes, nerve, kidneys, heart etc. ${ }^{1}$ The present study was aimed to measure body composition and evaluate the association of the stature, body mass index, waist circumference, waist to hip ratio, fat $\%$ if any with type 2 diabetes.

\section{Material And Method}

This is a cross sectional study carried out from Oct 2011 to Sep 2012 in the Department of Physiology, Regional Institute of Medical Sciences (RIMS), Imphal. 100 known cases of Type 2 diabetic patients aged 30 to78 years were selected after getting approval from the Institutional Ethical committee. Those patients associated with pregnancy, edema, fever, patients with pacemakers, heart diseases, patients on dialysis, body builders and professional athletes were excluded. Height, weight, waist and hip were measured following the guidelines given in WHO expert committee. ${ }^{9}$ Body composition was measured by using Omron Body Fat Monitor (HBF 306, OMRON HEALTH CARE CO., Kyoto, Japan).Omron Body Fat Monitor measures the body fat percentage by the Bio electrical Impedance (BI) method. The results of the study are statistically analysed as using mean \pm SD and followed by Pearson correlation. 


\section{Results}

Out of 100 patients, $76.5 \%$ of the patients gives a history of weight loss after diagnosis and starting treatment. $68 \%$ of the patients were on oral hypoglycemic drugs, $20 \%$ on insulin injection and $3 \%$ not on any treatment.

Table 1. Baseline characteristics of the study population.

\begin{tabular}{|l|l|l|l|l|l|l|l|l|l|l|}
\hline Groups & $\begin{array}{l}\text { Age } \\
(\text { years })\end{array}$ & $\begin{array}{l}\text { Height } \\
(\mathrm{cm})\end{array}$ & $\begin{array}{l}\text { Weight } \\
(\mathrm{kg})\end{array}$ & $\begin{array}{l}\text { BMI } \\
\left(\mathrm{kg} / \mathrm{m}^{2}\right)\end{array}$ & $\begin{array}{l}\text { Waist } \\
(\mathrm{cm})\end{array}$ & $\begin{array}{l}\text { Duration } \\
\text { of Diseas } \\
(\text { years })\end{array}$ & $\begin{array}{l}\text { FAT } \\
(\%)\end{array}$ & $\begin{array}{l}\text { HbA1C } \\
(\%)\end{array}$ & $\begin{array}{l}\text { PBS } \\
(\mathrm{mg} / \mathrm{dl})\end{array}$ & $\begin{array}{l}\text { FBS } \\
(\mathrm{mg} / \mathrm{dl})\end{array}$ \\
\hline Male & $54.3 \pm$ & $163.6 \pm$ & $66.4 \pm$ & $24.7 \pm$ & $0.96 \pm$ & $6.51 \pm$ & $28.5 \pm$ & $7.85 \pm$ & $274 \pm$ & $164.4 \pm$ \\
& 12.60 & 5.9 & 7.4 & 2.98 & 0.08 & 5.26 & 6.18 & 1.95 & 10.2 & 11.4 \\
\hline Female & $53.4 \pm$ & $152.4 \pm$ & $60.43 \pm$ & $25.9 \pm$ & $0.97 \pm$ & $7.5 \pm$ & $35.8 \pm$ & $7.89 \pm$ & $257 \pm$ & $163 \pm$ \\
& 9.25 & 5.64 & 9.29 & $3.24 *$ & 0.1 & 6.0 & $4.9 *$ & 1.90 & 8.8 & 13.4 \\
\hline
\end{tabular}

All data are expressed as mean $\pm \mathrm{SD}, * \mathrm{P}<0.05$

Table 1 shows the mean (SD) BMI was $24.7 \pm 2.9$ (males) and $25.9 \pm 3.4$ (females). The mean (SD) fat percentage was $28.5 \pm 6.2$ (males) and $38.5 \pm 3.2$ (females).The average waist/hip ratio (WHR) was $0.96 \pm 0.1$ (males) and $0.97 \pm 0.1$ (females). Table 2 study shows a significant correlation between body mass index and fat $\%(r=0.84)$ and BMI and weight $(\mathrm{r}=0.64)$. No significant correlation was found between BMI and HbA1C $(\mathrm{r}=0.13)$ between BMI and WHR $(\mathrm{r}=0.07)$, BMI and age $(\mathrm{r}=0.37)$.

Table 2. Correlation of BMI with body parameters

\begin{tabular}{|l|l|}
\hline FAT\% & $r=0.84$ \\
\hline HbA1C & $r=0.13$ \\
\hline FBS & $r=0.09$ \\
\hline Height & $r=0.19$ \\
\hline Weight & $r=0.67$ \\
\hline WHR & $r=0.07$ \\
\hline Age & $r=0.37$ \\
\hline
\end{tabular}

\section{Discussion}

The present study showed a wide range of age distribution in both males and females. The mean BMI was above the normal range in both male and female which is an important risks factor for diabetes. ${ }^{7}$ The association of BMI, waist circumference, waist/hip ratio and diabetes was observed by Gabriela and co workers. ${ }^{9}$ BMI was found to be correlated with the body parameters like weight and fat $\%$ measured. The fat $\%$ was higher than the ideal value as predicted by WHO. ${ }^{8}$ The fat $\%$ was higher in females as compared to males; this could be due to difference in body fat determined genetically The waist/hip ratio (WHR) was 0.96 and 0.97 in male and female respectively. As a general rule (WHR) $\geq 1.0$ considered at risks associated with being overweight and WHR of $\leq 0.90$ (men) and $\leq 0.85$ ( women) is considered safe for women (NIH 2004). Likewise waist circumference $>40$ for men and $>35$ for women associated with risk of disease (CDC 2004). ${ }^{10}$ Recent reports document association of waist circumference as a powerful predictor of type 2 diabetes with individual with waist circumference in the highest quartile having an 11times greater risk of type 2 diabetes than those with a waist circumference in the lowest quartile (Wei et al). ${ }^{11}$

The mean Hbalc was found to be above the normal value for diabetics $(\leq 7)$ which indicate that the subjects are not under control. The HbA1C level was not associated with body fat \% nor BMI nor duration of the disease which in similar to other studies. Nonetheless, researches have shown that even among healthy adults, body composition can vary significantly based on ethnicity, age and gender. ${ }^{12}$ This study has certain limitations. The cross sectional design makes it impossible to examine the time course for development of the observed differences and more over the study population is small. Most of the patients (76.5\%) had a history of weight loss after diagnosis and after starting treatment.

\section{Conclusion}

This study demonstrate that BMI, Fat \% and waist/hip ratio has an important role in the development of type 2 diabetes but the duration of diabetes and Hba1c is not associated with BMI or body fat $\%$. The Body fat $\%$ and $\mathrm{BMI}$ is found to be higher in female diabetics. 


\section{References}

[1] Powers AC. Diabetes Mellitus. In: Fauci AS, Braunwald E, Kasper DL, Hauser SL, Lango DL, Jameson JL, Loscalzo J, Editors. Harrison's Principles of Internal Medicines, $17^{\text {th }}$ Edition. New York: McGraw-Hill: 2280-2282.

[2] Singh TP, Singh AD, Singh TP. Prevalence of diabetes mellitus in Manipur. Journal Diab Assoc India 1997;37:41-46.

[3] Shah SK, Saikia M, Barman N. High prevalence of type 2 diabetes in urban population in North Eastern India. Int J Diab Dev Countries 1998; 18:97-100.

[4] Chan J M, Rimm EB, Colditz GA, Stamfer MJ, Willett WC .Obesity, fat distribution and weight gain as a risk factor for clinical diabetes in men. Diabetes Care 1995;17(19):961-969.

[5] Hans TS, Feskens EJM, Lean MEJ, Seidell JC. Association of body composition with type 2 Diabetes Mellitus Diabetic Med 1998;15:129-135.

[6] Lean MEJ. The role of central fat accumulation in type 2 diabetes. Br J Diabetes Vasc Dis. 2001; 1:115-117.

[7] Stanley Heshka, Andrea ruggerio, George a bray, et al Altered body composition in type 2 diabetes mellitus. Int J Obes 2008;32(5:)780-787.

[8] 8. Gabreila, Sue, David R et al. Comparison of BMI, Waist, Waist hip ratio in predicting incident diabetes :A Meta Analysis. Oxford Journal Medicine Epidemiologic Review. 29:115-128.

[9] 9. WHO Expert consultation. Appropriate body mass index for Asian populations and its Implications for policy and intervention strategies. Lancet 2004; 363(9403):157-63.

[10] 10. Coldditz GA et al.Weight gain as risk factor for clinical diabetes mellitus in women. Annals of Internal Medicine 1995,122,481486.

[11] 11. Heyward VH, Stolarczyk LM 1996. Applied Body Composition Assessment. Champaign, IL: Human kinetics.

[12] 12. Body composition and presentation of type 2 diabetes mellitus. Diabetes and Primary Care 2008,Vol 10, No 4;208-218. 